\title{
EEN BEZOEK AAN DE NIJVERHEIDS-TENTOONSTELLING TE HAARLEM, I86I.
}

Haarlem is feestelijk getooid. Gaan wij er heen, doch niet voor de feesten, althans uiet voor 't gejocl en 't gejuich en de muziek, - welke een regtmatige hulde ook de schooue muziek-corpsen mogen verdienen die, volgens echte free-trade beginselen, door de commissie uit het buitcnland zijn ontboden, een stilzwijgende lulde aan den nuttigen nijverheids-regel, dat elk verbruiker zich dáa moct voorzien, waar hij best zijne gading vindt. - Gaan wij liever vaar Haarlem voor het ware feest, het feest der nijverheid! De vlag van den St. Bavo roept uit de verte, en wenkt over tuinen en velden den bezoeker naar de grijze stad.

Het feest der Nijverheid! Maar wat zal dat geven? Zijn wij eigenlijk wel een nijverheids-rolk? Stel, wij komen over Amsterdan, is het niet alsof alles ons verwijst op andere takken van bestaan dan het fabriekwezen? Het mastbosch even in de dokken begluurd; het drukke vertier aan den IJkant; de velden van den Haarlemmermecr-bodem, thans met graan en hooi bedekt en met woningen doorzaaid, en een lagchende vlakte aanbiedende voor het oog, waar de spoorweg-passagier te Halfweg nog onlangs niet dan plassende golven ontwaarde; - de vischschuiten in het $\mathrm{IJ}$, en de bloemvelden van Haarlem, roept dat alies ons niet toe: Wij zijn een land van polders en kaasmakers; een land van landbouwers, visschers en kooplieden, maar wij zijn geen industrieel land, als Engelaud of België? - Och, dat oude voorvordeel, alsof nijverheid alleen aan het bezit van steenkool en jizer in den bodem ware verbonden! Laat ons dat denkbeeld toch vaarwel zeggen: niets is nadeeliger: voor ontwikkeling, dan de meening: ik kan niet! Alles kan, waar de krachtige, zedelijke, goed ondersteunde wil aanwezig is, - en 't is maar' zeker waar, qui dit: je ne peux pas, dit: je ne veux pas! Als wij erustig willen, als wij de vereischten voor industrie maar zoo toegankelijk mogelijk willen houden, door onbelaste brandstof en oubelast vleesch, dan zullen de kundige menschen uit de meergevorderde standen daar wel genoeg partij van weten to trekken, en dan zal zich gaandeweg een kundige arbeidersbevolking vormen; met onze ligging, onzc débouchŕs, ons taricf, onze gelegenhcid tot aanvoer van jjzer en steenkool, kan men niet zeggen dat wij 
geen industrieel volk kunnen zijn, gelijk dam ook tronweas de vorderingen der laatste vijftien jaren dit over ev over antoonen. - Doch nu naar Haarlem. -

Het was een schoon dentbceld der Maatschappij ter bevordering van Nijverheid, om telken vijf jarcu eene uationale tentoonstelling te houden. Hoewel let mijn voornemen geenszins is, hier de tegenstanders van tentoonstellingen te bestrijden, erken ik rolmoudig, tentoonstellingen te houden voor een der beste middelen om den gepasten uaijver der producenten op te wekkeu, maar bovenal ook voor welligt het eenige middel om op Nederlandschen bodem iets over te planten van dien nationalen nijverheidstrots dien wij bij andere volken opmerken, en die daar soms overdreven wordt, doch bij ons te veel ontbreekt. Het is in Nederland alsof de consunenten een afkeer hebben van inlandsch fabrikaat, en er niets goeds kan wezen of het moet uit den vreende worden aangevoerd. Dat men toch eindelijk eens begrijpe, hoe dikwijls door fabrikanten en winkeliers met die zucht tot buitenlandsel fabrikaat de spot rordt gedreven, en hoeveel inlandseh fabrikat meu gebruikt, onder vreemde namen! Worden er hollandsche opschriften op geplaatst, dan is het fabrikaat spoedig veroordeeld, doch heeft men er cen vreend klinkcnde, dikwijls barbaarsche naam aan kunneu geven, ja, dan wordt het verkocht.

Ik weet het, er zullen velen zijn die mij toevoegen, dat dit wel nu en dan geschiedt, duch ditt ik bet anti-nationale der Nederlauders bier veel te hoog opvoer en te breed uitmect. Ik neem hum dit nict euvel, want het grootste gedeelte der bevolking van ons land is niet bekend met de duizcnde gelegenheden, waarbij men zich inlaudsch fabrikaat voor vreemd in de handeu laat stoppen, en het dikwijls daarom duurder zal betalen, zoodat volmaakt hetzelfde artikel tegen verscbillende prijzen wordt verkocht, al naarmate het van hollandsche of vreende etiquetten is voorzien. Onder de consumenten worden cr ook gevonden, die nog niet weten, wat onze inlandsche industrie wel oplevert, en zich daardoor enkel uit onbekendheid, van buitenlandsch fabrikaat voorzien. Aan ben voornamelijk raad ik aan, de tenloonstelling to bezoeken; daar zullen zij de overtuiging erlaugen, dat Nederland mecr nijverheidstakken bezit, dan zij welligt ooit hadden gedacht, en.... doch nu uiet verder uitgewijd over tcntoonstellingen in 't algemeen, en begrippon van natioualiteit op het gebied der nijverheid. Laten wij ous naar Haarlem spoeden, on dar te zieu wat er sehoon, nuttig en bruikbaar is, en de loogte waar te nemen waarop onze nijverheid staat.

Het doel is thans geenszins on hier cene beschrijving te geven der voorwerpen, nog veel miuder om eeue bcoordeeling necter te schrijyen, en daardoor het werk der Jury vooruit te loopen, maar ik wensch alleen met den lezer eene wandeling te maken door de verschillende zalen, en hier en 
daar iets merkwaardigs aan te stippen; ik wensch een cicerone te zijn, voornamelijk voor die zaken, welke miet zoo dadelijk in het oog vallen, of waarvan men juist niet dadelijk het nut, of het moejelijke der bewcrking inziet.

Welaan dau! nemen wij onze entrée-kaarten aan 't bureau, voorzien ons van een catalogus, daar in den hoek, stappen het bordes op, en zie, wij bevinden ons in de zaal No. 1. Als maatregel van orde is door de commissie, die alles behalve rëactionair is, het verbod van terugkeeren uitgevaardigd; wij moeten dus alles naanwkeurig in oogenschonw nemen, daar hier de spreuk ook geldig is, vooral op sommige punten der zalen, "stilstand is achteruitgang". Moge de incustrieele die spreuk ter harte nemen!

Het eerste wat ous in 't oog valt zijn de goudsche pijpen. Die kwijuendo tak van uijverheid sehijnt bet hoofd boven te willen houden door keur en verscheidenheid van vormen, iets hetgeen eenc ceur geleden uiet noodig was, daar de sigaren toen de goudsehe pijp nog niet hadden verdrongen. Daarboven vinden wij het bellenbord van de Wed. IJzersas \& Zoon te 's Hage, maar tegen den muur op don grond, is het muurtje van roetsteen gemetseld, neĉrgezet, ingezonden door J. D. KAAKKBEEN te Haarlem. Dit is eene zaak vau grooter gewigt dan men misschien zon denkeu, doch roetvlekken uit muren weg te maken blijft immer nog cene wenschelijke zaak.

Vervolgens zien wij de wapens van Wlllex Pauwels \& ZN, te 's Hage en S. DE JAGEl te Haarlem, die cen goed denkbeeld geven wat in dit vak in Nerlerland wordt gemaakt.

Kecren wij ons om, dan vallen dadelijk de verschillende gazkroonen in het oog, van J. L. Nering Bögre \& Cie. te Deventer en H. A. A. KioosTERHUIs te Amsterdam, waarvan voormamelijk de ecrste onze aandacht verdient, als een stuk, dat niet door kostbaarheid van materiaal maar door bewerking zich onderscheidt.

Daar onder, op de tafel, zien wij eene verzaneling geverwd en verlakt blik- en zinkwerk, dat niet onaardig bewerkt is; icts verder een pistool van J. J. B Brgelaar te Rotterdam, (als twee geweren in den catalogus vermeld) benevens monsters-jagthagel van Huisuan \& Cie. te Groningen en Wed. G. Dooremans \& Zn. te Rotterdam.

Onder de verschillende deur-, kamer- en raamsloteu dic wij hier aantreffen, verdienen vooral ouze aandacht, de in de toonkast geplaatste, waaronder zich er een bevindt hetwclk ook sluiting heeft in de slotplaat en zeker hoogst veilig mag genoemd worden; de naan van den inzender was echter voor mij niet te vinden.

Op de tribune vindeu wij vijlen uit de kapperij van G. WATson \& $\mathrm{ZN}$. te Rotterdan, die er zeer goed uitzien; zijn zij goed gehard? de kunstvijl had de inzender wel te huis kunueu houden, daar deze niets beteekent; indien ik mij niet bedrieg hebben wij reeds vroeger op eene tentoonstelling met dat ding kennis gemaakt. Voorts fraaije, zeer fraaije bronzen of liever gebronsd zink van Scroutz te Zeijst. - Welk een goede stijl en zuivere vormen! Dat doet goed om te zien als Hollandsch product.

Keeren wij weder tot het middenvak terug, dan vinden wij daar op den tafel de beide zeer net bewerkte modellen van H. H. Dansporp te Haarlem, eene ijsschaaf en de daarbij behoorende opruiningsrol, doch komt 
deze imrigting misschien wat laat, daar bij de doorgraving van Holland op ziju smalst, er minder behoefte aan zal wezen; het denkbecld is echter zeer goed en de modellen zijn keurig bewerkt. Iets verder staat weder eene verzameling lak-en koperwerken van de Wed. J. Bekrens \& ZN. te Dordrecht, warbij wij a opmerkzaam maken op het wuschtafel-garnituur, dat in vorm en verlakwerk, groote overeenkomst heeft met porselein.

Indien wij ons nu omwendeu, om ook de goederen langs den muur geplaatst in oogenschouw te nemen, dan zien wij daar eene verzameling proeven van imitatie van mamer en houtsoorten, ingezonden door G. H. BaUER te 's Huge, Gebrs. Surts te Rotterdam en anderen, waarbij wij vooral de salondeux van W. G. F. Huymaxs niet moeten overslaan. Daabij zien wij het brandsignaal van de Wed. M. IJzem an \& Zn. te 's Gravenhage, benevens de kast net wapenen van P. Stevens te Maastricht. Den klein eind wegs verder staat het model van een mangel, die altijd naar denzelfden kant gedraaid wordende heen en weder gaat, van eene alleraardigste constructie, ingezonden door (in deu catalogus niet te vinden). Vervolgens bezien wij weder gietwerk van L. Schurz te Zeist, en het schellebord van J. E. Scrurrz \& Zu. te Haarlem, waama wij de zaal verlaten en ons in de volgende begeven.

Hier zijı wij op eenmaal in eene geheel andere sfeer verplaatst. Het eerste waar ons oog op valt zijn de chenicalien van J. Mouron \& $\mathrm{Zn}$. te 's Hage en eene rol kleefpleister van Groots \& Ruarexy te Amsterdam. Verder vinden wij alle soorten van praeparaten, scheikundig zuivere reagentia, photographischen chemicalien en verschillende zuren, waarvan wij eigenlijk niets kunnen zien, liet aan de Jury overlatende on de waarde er van te bepalen. Wij moeten echter do inzending van zestig verschillende ijzerpraeparaten van K. G. W. DE Bossun te Dordrecht, niet over het Loofd zien eene merkwaardige collectie. Gaan wij verder dan vinden wij de verduurzaande leveusmiddelen van A.J. vas Hoxtexs te Culemburg, beneveus de prachtige suikerbrooden der Nedcrl. suikerraffinaderij te Ansterdam, die onze aaudacht overwardig zijn. Alvorens deze zaal te verlaten bezien, wij het schoone, in de vensterbank geplaatste stuk gesublimeerde salmoniak, als representeerende een tak vau Amsterdamsche nijverheid, ingezonden door VAN DER ELST \& MATThes aldaar.

Op den overloop of het portal naar zaal 3 vinden wij angemaakte verwen, kunstmatige minerale wateren en monsters azijn, zeep en stijfsel; daar in den hock, bij de monsters hard brood en beschuit, proeven van nabootsing val houtsoorten, van MoLys \& Cie. te Rotterdam. Deze zijn niet als gewooulijk uit de hand gesehilderd, maar met de duarbij geplatatste lederen rollen, als het ware machinaal bewerkt. Konners zijn het niet met elkander cens, of deze manier van werken goed of niet goed is, dooh zeker ziju deze monsters keurig en niet stijf.

Op zaal 3 gekonen, wordt ons oog dadelijk geboeid door de stearine kaarsen welke wij daar ontuocten. Deze nijverheidstak is in ons land tot eene groote outwikkeliug gerankt, en mag als voorbeeld voor undere verstrekken, wat door volharding kan verkregen worden. De teutoougestelde voortbrengseleu zijn uitmuniend en wij zouden ouregtvaardig wezen door den eem boven den auder de voorkeur to schenken en vermelden daarom alleen, dat de inzenders ziju: de HH. D. v. D. BEhg \& J. v. Rodenberg te Amsterdan; Brandon, Mendalpho en J. Chr. Dhuyvestein te Ansterdam, alsmede van Irerson te Gouda. Links cn regt vau deze zaal viudeu wij glaswerk, porcelein en aardewerk van P. ReGovt te Maastricht, waar 
onder twee glazen buizen, die zeer merkwaardig zijn, wijl zij twaalf jaren te Maastricht in gebruik zijn geweest en niet blijken daardoor geleden te hebben. Voor de ramen vinden wij de albasten vazen van $C$. $H$. DE HAART te Utrecht, benevens de prachtig met de diamant gegraveerde glazen vax $\mathrm{D}$. H. DE CAstro te Amsterdam. Bij al dit schoone mogen wij de flesschen van Mevirsing \& Comp. te Nieuw-Brunen uiet over het hoofd zien, daar dit product zoo veelvuldig uit Duitschland wordt aangeroerd en het blijkbaar hier te lande even goed verkrijgbaar is. De prijzen ziju. ons onbekeud; kunnen die welligt oorzak zjju vam den grooten toevoer uit den vreende?

Bij het binuentreden der voorste zaal, verwonderen wij ous of liever wij staan verbaasd over den plotselingen overgaug, want wij bevindeu ous op eenmaal tusschen suikerwerk van allerlei aard, omgeven van kleeden en karpetten. A. M. Karis te Rotterdam en G. C. C. ReEsen te Huarlem hebben een pracht van suikerwerken geexposeerd, terwijl $A$. VAN WALRAVEN te Rotterdam ons onthaalt op een groote koek. "Maar dat is geen nijverheidstak", znllen sommigen zeggen, doch roorwaar, de koekbakkers maken een goed deel der uijverbeid nit. Ik heb meermalen de verzekering erlangd dat er een koekbakker is die 1200 pond brokken of kussentjes per wcek debiteert; voorwaar cen aardigre omzet in zulk een artukel.

Wat verder komen verschillende kintwerken van de school te Sluis, van G. Sromers te Eindhoven, Gez. Bos te Meppel, A. Weijermaxs te Oosterhout, en anderen; van dezen laatsten zagen wij met genoegen den parasol en ook de kant voor ecn altaardwaal, die vooral, wat de teekening aangaat, voorstellende vijf episoden nit de omwandeling van Christus, zeer goed is, hoewel ik hob hooren vertellen, dat de kunst niet zoo groot is van dit stuk als kautwerk; ik wil het gaame gelooven, doch het heeft de verdienste vau beter van teekening le ziju, dan men zulks gewoon is.

Verder doorgaande vinden wij van zelve de groote kast met borduurwerken van F. Sroutzenseng te Roermond en zien de daarop geplaatste crinoliue. Vervolgens wijst alles iu deze zaal zich van zelve; de watten van A. BrevtredT Azu. te Delft vindt men er ook, misschicn ziju cr wel antirleumatische bij, die voor de lijders an die kwal beterschap boloven. Regt over de kast net borduurwerkon vinden wij de loogst belangrijko expositie van Previnatre \& Comp. to Hanrlem, waarin cen tal van zaken voorkomen voor de O. I. markt, doch vóor wij daar zijn moeten wij niet vergeten eenige oogrenblikken te wijdcu an de beschouwing der keurig geverwde monsters vloszijden ran J. DE BReuk \& Zx. te Hairlem.

Misschien is ex bier veel merkwardigs te zien, miar daar alles bij pakken en stukken is tentoongesteld, en men hetgeen open is opgehangen, volstrekt niet mag aanraken, 200 blijft hier menge parel in le schulp, daar de bezoekers geen hunner zintuigen nogen gebruiken, dan de oogen. De Jury alleen zal kumuen genieten val het voorregt van betcr te mogren waarmemen. Door J. KamerLng \& $\mathrm{Zr}$. te Almelo is van den regel afgeweken; daar zij den bezoeker vragen aan de rol damast vau 20 patronen te draajen en ze alle te bezien. Door J. A. P. Beuderen te Utrecht is een tapijt geexposeerd uit 100 stukken bestamude en met rood laken algezet. Bij het lezen van den catalogus dacht ik aan 100 versehillende diersoorten, doch de beteekenis blijkt te zijn van 100 dieren, in ecnige soorten.

Nadat alles behoorlijk bezien is gaan wij naar zaal 5 , war weder geheel andere zaken zijn geplaatst. Het eerst wat wij ontmoeten zijn die keurige modellen voor de theorie der kromme lijnen van cukelc en dubbele krom-

BuBL. ECON. 1861 . 
ming, benevens die voor het geluid en het licht, ingezonden door L. JANSE Bz. te Middelburg. Deze modellen zullen bij het onderwijs onberekenbaar nut kumnen geven, doch voor klassikaal onderrigt zonden wij ze wat grooter wenschen. Verder vinden wij de meteorologische werkthigen, waaronder wij a opmerkzaam maken op de schoune nevelbarometer van J. F. van Deene, te Amsterdam. Vervolgens de physische werktuigen van H. Deurgen te Groningen eu dan het nieuwste, dai wij op de geheele tentoonstelling liebben opgemerkt, namelijk de galvanoplastisch vervaardigde zilveren voorwerpeu van L. J. S. VAN KeMPen te 's Hage. Velen hebben zich bezig gehouden en doen het nog met de galvanoplastiek, doch werken dan uitsluitend in koper, en waarom? ondat dit metaal het gemakkelijkst te bewerken is langs den natten weg, maar zilver hebben wij nog niet onder de oogen gehad, inlandseh fabrikaat, dan van den inzender. $\mathrm{Hij}_{\mathrm{ij}}$ leeft een tak van kunst-industrie op Nederlandschen bodcm overgebragt, waarvoor wij hem dank zeggen en waarvoor hij alle aanmoediging verdient. Daar in de rondte zien wij monsters behangselpapier uit de fabriek van J. Wispoogen Jzn. te Amsterdam, met de vornen er onder geplaatst, waarmede de patronen zijn gedrukt. Op den tafel, hier aan den hoek, staat de aluminium-balans van H. Oluand te Utreclut en aan de overzijde de guilocheer-machine van J. W. Menser te Amsterdam, welke beide zaken de aandacht der bezoekers verdienen. Op het schoone verlakwerk van L. J. NooIJes te Rotterdam behoeven wij niet te wijzen, daar dit genoegzaam in het oog valt, maar daarentegen wel op de zoo zuiver bewerkte toestellen van Gebrs. Camrnada te Rotlerdam. Zij kunuen volkomen met het buitenland wedijveren in zuiverheid van bewerking en naauwkeurigheid en het zijn niet alleen de voor deze tentoonstelling vervaardigde voorwerpen, maar wij Lebben partijen instrumenten van deze heeren gezien, die niets te wenschen overlieten. De toestellen van P. J. Kupp te Delft voorbijgaande viuden wij van J. A. Schok KING te Amsterdau een windkrachtmeter van eene nieuwe inrigting, die de beschouwing overwatardig is, en slaan wij even het oog nitar boveu om de drukproeven sans fin, van JoH. ENschedé \& Ziv. te Haarlem te bewonderen.

$\mathrm{Nu}$ zijn wij op eemmaal als het ware verplaatst tusschen photographien van versehillende iuzenders, die alleu hun best hebben gedaan, doch waarvan de een gelukkiger proeven heeft gegeven dan de ander. Wij behoeven lier niet lang bij te vertoeven, bij de groote concurrentic in dit vak ziet men tegenwoordig overal goede photografie-tentoonstellingen op straat. Beschouwen wij liever de etalage van E. P. YAN Osch te Maastricht die, althans naar het uiterlijke te oordeelen, eene regt schoone collectie koperen blaasinstrumenten heeft ingezonden. Vervolgens viuden wij hier niet op zijne plaats, de verzameling van papier vau Lhoest Lamaers \& Comp. te Maastricht; de strijkinstrumenten van C. WEeL te Utrecht, en eindelijk de physische instrumenten van F. W. FoNCKLER, die de grootste belft zijner instrumeuten heeft gemaakt naar Logeman's inrigting. Is die inrigting zóó goed om ze altijd te volgen? wij meenen het te betwijfelen. Het zijn soms niets beteekeneude veranderingen, die nog niet altijd rerbeteringen kunnen heeten.

Deze zaal ten einde zijude, spoeden wij ons over de beide portalen, waarvan bet cene zwoegt onder een last van inlandsche producten: cigaren en tabak, en het tweede behangen is met dekens, naar de volgende zaal, gemerkt met No. 6 , en beviuden ous te midden van verschillend lederwerk. 
Deze zal is voor iedereen gemakkelijk te overzien, daar het meest dagelijksche zaken ziju die er op voorkomen. Schoenen en laarzen met leesten zijn toch alleen in het gebruik te beoordeelen, minsteus moet meu ze in handen kunnen nemen, doch de drijfriemen, daar achter in dien hoek, van A. Avam te Delit weten wij bij ondervinding dat goed van bewerking ziju, vooral zijı zij bijzouder goed gerekt, en daarom vestigen wij er de aandacht op. Wij bezien vervolgens de laarzen en schoeneu van A. VAN DER Suuiss \& Cie. te Amsterdam en P. Theunissen te Rotterdam, en begeven ons langs springmatrassen, bedden en kusseus naar verschilleude verzamelingen van voorwerpen, die uit industrieel oogpunt geen waarde bezitten, en naar onze meening op deze tentooustelling niet gevonden moesten worden, wijl zij niet de hoogte leeren zien, waarop de eigenlijke mijperheid gekomen is, en dat toch altijd wel het hoofddoel zal wezen en blijven eener nijverheids-tentoonstelling. Wij bedoelen de collectien ingezonden van wege het blinden-instituut te Amsterdam, het krankzinuigen-gesticht te Meerenberg bij Haarlem etc.

Aan den anderen kant vinden wij de glacé handschoenen van H. VIgeuIJS \& Cie. te Rotterdam in hunne verschillende stadicn van bewerking, waardoor niet onaardig wordt aangewezen, hoe eene handschoen eigenlijk in de wereld kont.

Eindelijk bij het verlaten der zaal vallen ons eene reeks reiskoffers in het oog, die nog al aanmerkelijk is, en warvan wij, voor zoo ver eene bloote beschouwing het toeliet, de aandacht meenen te moeten restigen op den dames-reiskoffer met nieuw zilver gemonteerd van L. PELGER te Amsterdam en den heeren-rciskoffer van A. P. Surs te Breda, die beide door doelnatige inrigting zich onderscheiden.

De zaal waar wij nu binnentredcn, heeft meer van een groot portaal dan van zaal No. 7, doch zij is groot genoeg voor het aldaar geplaatste.

Vooreerst vinden wij de enorme etalage uit de koninklijke fabriek van gouden en zilveren werken van J. M. VAN KEMPEN te Voorschoten, die geen verdere aanwijzing behoeft, maur elks attentie genoegzaan trekt. Vervolgens de vaas van P. ne Meisen te 's Hage, waarvan de catalogus genoegzaam zegt; en de schoone degelijke zilver-producten van BoNeBAKKER te dmst. en anderen, daarna gezette diamanten vau $\mathrm{D}$. Rosuns te Rotterdam, benevens diamanten ingrezonden door M. E. Coster en J. M. Posno, beiden te Amsterdam. Wij meenen den bezoeker hier opmerkzaam te muetcn maken op het kastje net diamant-modellen van M. E. Coster, dat van de noodige opschriften is roorzien, cn ons in de gelegenheid stelt van kennis te maken met den vorm en de grootte der wereldberoemde diunanten „Kohi-nolir", "étoile du sud" enz.

Op het" portaal, dat van deze zaal naar de volgende leidt, vinden wij de aambevolen photographiselie albums van F. W. Rinck te "s Hage en de modelkast met penseelen, trekkers en kwasten van C. Keer CzN. te $A$ msterdam. De zaal No. 8 binuentredende, wordt onze aaudacht dadelijk geboeid door een nieuw driekant schaakbord van E. v. D. Sruon \& $Z_{N}$. te Haarlem. Vervolgens links en regts ziende vinden wij cartonwerk en kantoorboeken van verschillende, benevens eene groote collectie zilverwerk en vitrines tentoongesteld, welke artikelen des bezoekers andacht genoegzaam zullen trekken zonder dat er eenige aanwijzing voor noodig is. Doch hier regts vinden wij de glazen mozaik letters van E. Wessels te Rotterdam, de natuurdruk van J. S. WILson te Meppel, en de proeve van chromolithographie of kleurendruk, ran B. W. IJzerdraAd te 's Hage. Ook hier was 
het een zeer gelukkig denkbeeld, om afdrukken te geven van de plaat, bij elken nieuwen stap der bewerking. Deze proeve moeten wij van nabij bezien, want zij is schoon, zij gecft op eene bewonderenswatardig naauwkeurige wijze de origineele teekeuing terug, en mag als cen nieuwe kunsttak worden aangemerkt, waarvau veel goeds te verwachten is.

Daur, in die kast met ivoor van S. H. T. Wernen te Amsterdam, moeten wij even de rotting beschouwen die er in is geplaatst, als een eenig stuk, dat niet dikwijls voorkont, Voortgande komen wij aan de inlandsche papieren, wit en gekleurd, tiju en grof, dik en dun, ingezouden door verschillende fabrijkanten uit Gelderland en van de Zaan, doch staan even stil bij het nieuwe behangselpapior, ingezonden door Emanesco \& Rrenink, als het goedkoopste behangsel dat kan bestian.

Al voortgaande viuden wij proeven vit de lettergieterij van Jor. ENscaedé \& $Z_{N}$. te Hatarlem, waarvan wij nicts afzonderlijk kumen opseven daar alles even goed uwe aaudacht verdient, maar vestigen toch uw oog op de stereotype plant, waarop de grondwet is gedrukt; hoe klein, maar toch hoe rein! Wat verder, aan het einde van deze tafel viuden wij monsters van eene nieuwe uitvinding der latste twee jaren, perkamentpapier, eene stof waurvan veel roep is uitgergan, als ware zij voor alles even dienstig, doch waarvan de toejassing schipbreuk heeft geleden, en die weder naar let laboratorium zal terugkeercn om de dinorphe toestand van katoenvezel te bewijzen, zonder meer.

Op het portaal vinden wij verschillend meel van de matschappij de Korenschoof te Utrecht en gasmeters van W. C. Pastrur \& Cie te Rotterdam en Bryan De Groot \& Cre. te Schicdam. Gasmeters zijn nog nooit op nationale tentooustellingen, voor zoo ver wij ous herinneren, tegenwoordig geweest en let is dus ecne buitenlandsehe industrie, op vaderlandschen bodem overgeplant. $O_{p}$ het corridor mar zal o vinden wij eene groote collectie landbouw - en tuinzalen, benevens twee vitrines mot gedroogde bloemen van E. H. KrelaGe \& Zn. te Haarlem. Die gedroogde bloemen en mossen zijn uitnemend om in die gevallen gebruikt te worden waar men geen levende bloemen kau toepassen, daar vorm en kleur bijzouder goed zijn bewaard gebleven. Bij let algaan van den trap stuiten wij tegen den prachtigen schoorsteenmatel van $D$. WeEgewiss te Amsterdam en bevinden ons aan den jugang van zaal 9 .

Hier in de grootste zaal, waar tevens de ingang naar de buffetten is, is bijzonder veel te zien, doch er is voor mij hier bijzonder weinig op te merken, daar de catalogns alles duidelijk aanwijst en bovendien de grootte der stukken ieder in de gelegeuheid stelt, on zouder inspanning alles te zien. Het ziju meer dagelijksche zaken die nu volgen, zoodat ik mijne medebezoekers nu wat aan hen zelven zal overlaten en hier en duar mal wat aanstippen. Wij gaan dus de weefretouwen, de rijtuigen en do paardentuigen voorbij en merkeu hier alleeu op de naai-machine van J. Lunoerass te Rotterdam. Er komt meer spraak over naa-machines in den latsten tijd, en misschien zal het niet lang meer duren, of elke vrouw zal er een bezitten; dat is dus een belangrijk werktuig voor de inlaudsche industrie. Voortgaande vinden wij voorbij den ingang naar het buffet, de veiligheids-locomotief van R. F. Matrland te Amsterdam, eene onde bekende, wien het altijd nog aan practische waarde mankeert.

Nu de Jacobijnenstraat over, en wij zijn in een der zalen van het Gymnasium gemerkt No. 10b, waar wij eene pruchtige verzameling meubelen en kleeden vinden. Het eene zal uwe aandacht trekken van het andere, doch 
bezie even het ingelegde werk van A. Boscr te Rotterdam, en het verlakwerk van E. T. D. STEOn \& ZN. te Haarlem en F. ZEEGERs te Amsterdam. Maar, van lakwerk gesproken, niets overtreft in ons oog, het nagemaakt Japansch en Chineesch verlakt vau Frassse te Haarlem. Alles is bier goed, zie dus ter dege in de rondte voor gij dit zaaltje verlaat en kom dan weder naar zaal 9 terug.

Juist waar wij hiser inkomen, liggen, als het ware verscholen onder andere zaken van grooten omvaug, de darmsnaren van T. BArriëL te Amsterdam, die de beschouwing over waardig zijn en een paar stajjes verder kunnen de dames de oorzak zien, warom het goed op de bleek zoo aan stuk wordt gewrongen: ik bedoel de hennepen wringdoek van de Wed. H. J. WILLEMs en P. DE JoNg te Haarlem. Jammer dat er nog altijd van die limnengoedvernielers gebruik wordt gemakkt en de centrifugaal droogtoestellen niet meer in gebruik komen,... ach, die vooroordeelen! doch niet getreurd, hum tijd zal ook wel komen. Wandelen wij de zaal door, dan vinden wij verder brandspuiten, en machineriën, eene schoone trophee van de Handelmaatschappij, papier-snijmachines en stoomwerktnigen, die ik volstrekt niet behoef aan te wijzen. Aan het einde der zaal bij den uitgang is in die groote glazen kast een torenuurwerk geplaatst, van de Wed. M. IJzerMan \& ZN., waarbij elke wals door twee gewigten wordt omgedreven, en waardoor de wrijving op de tappen bijna tot nul is gereduceerd. Van hier gaan wij naar het Prinsenhof, waar wij machineriën vinden voor Oost en West, voor fabrijkwezen en landbouw, die weder genoegzanm in 't oog vallen, doch wij moeten bier tegen dien muur het verschillende stafijzer bezien, van $W$. WoLTERs te Leijden, en de afgehakte en omgebogen einden gadeslaan om over de deugd er van te kunnen oordeelen; zic die ronde staaf eens met een kuoop er in! voorwaar dat schijnt goed ijzer te zijn dat gocd bewerkt is! Och ja, alle jyzer is goed, als het maar goed bewcrkt wordt, dat is de kunst.

Op het portaal naar, en in zaal 10 zelf, wordt onze aandacht gevraagd voor eene massa meubelen, die van alle kanten zijn ingezonden. In het portaal vinden wij het eerst eene etalage van verschillend draaiwerk van C. A. Frscher te Amsterdam en is de mozaïke salontafel van D. Siem te Amsterdam niet over het hoofd te zien. Het kuustmarmer van J. H. Pardies te Rotterdam verdient evenzoo voor eenige oogenblikken onze aaudacht. In zaal 10 worden wij onder mcer andere meubelen, aangenaam vergast op de beschouwing der voortbrengselen van HoRkIx te 's Hage, Sivm te Amst., Broers Appo te 's Hage, en Gemunr te Haarlem. Om al de inzenders van mooije meubelcn te noemen, zon te lang ophouden. Er is hier veel fraais. Een rand geven wij aan meubelmakers in 't algemeen, nl. om zich nog meer toe te leggen op schoonheid en gestrengheid vau rorm en stijl, dan wel op pracht van meubelen door verschillende houtsoorten en veel lofwerk. - Ten onregte denkt men soms dat veel lofwerk een meubel mooijer makkt. Wij zien hier menig stuk dat winnen zoude als er wat lofwerk wierd afgenomeu. De verbruiker houdt er ook niet altijd van: krullen zijn stofizesten, en de schrik der werkmeidon. Genr. Horrix hebben een gebeeldhouwden muzijklessenaar ingezonden, dien wij eens naauwkeurig noeten bezien, en er even voor stilstaan, want deze is lhet overwaardig. Wat ik $\mathrm{u}$ aanraad, bij het inkomen in deze zaal, ga niet te vlug, en bezie alles goed, waut mag het een meer in uwe smakk vallen dan het andere, alles toch verdient hier de aandacht, en gij kunt hier zien op welke hoogte het zoo nuttige meubelvak in Nederland staat. 
Deze deur door komen wij in een zaaltje met pianino's. Wat daar in zit is moeijelijk te zicn, en door elk stuk eens b. v. acht dagen in huis te bebben, zou men beter over de waarde kunnen oordeelen.

Bezieu wij ze dus oppervlakkig, doch daar op de pianino van J. J. ALLGaverr te Amsterdam, ligt een sterwork vau zijne constructie, net beweegbare metaalblokjes, die door schroeven kunnen worden vastgezet en waardoor de vork ondersoleiden toouhoogten kan aangeven, die er op gemerkt zijn. Daar in den hoek vinden wij het aconsticon voor pianimo's van L. J. LEFĖBRE te 's Gravenhage en wat verder de verbetering in het aanbrengen der snaren van J. J. NIsSEN to Amsterdam, waardoor het scheuren van den zangbodem wordt voorkomen. Wie nog niet weet hoe een piano er van binnen uitziet, kan zich van de mechanick cen denkbeeld vormen, door het beschouwen der afzonderlijke declen, ingezonden door Gebr. RiJken en De LANGe te Rotterdam.

In het portaal, dat van deze zaal gelegenheid geeft om naar de Pandplaats over te steken, zien wij eene collectie voorwerpen, afkomstig uit let krankziunigengesticht te Derenter, door daar verpicegde lijders vervaardigd. Bij gelegenheid der tentooustelling van nijverheid te Arnhem, was ook daar e ne dergelijke verzameling ingezonden, doch aan elk stuk was een billet gehecht, vermeldende den gemoedstoestand van den lijder, waardoor deze verzameling eene eigenaardige waarde verkreeg. Jammer dat zulks ook hier het geval niet is.

Op de Pandplaats gekomen, die als zaal No. 12 is aangegeven en daarvoor, door bijna geheele bedekking met glas, zeer geschikt is gemaakt, is de rigting moeijelijker aan te geven dan in de andere zalen, daar wij hier meer tusschen de verschillende zaken doorloopen en er daar achter weder andere vinden. Doch dit is van gering aaubelang, daar alles zeer gemakkelijk kan overzien worden. Beschouwen wij vooreerst uit de verzameling van N. vaN Hrukelum te Nijmegen de gebakken straatkeijen, koninklijk geoctrooijcerd, die als iets nieuws dienen bezien te worden; zij zien or op het oog goed uit, en de tijd zal moeten leeren, of zij goed voldoen. Bezien wij tevens de holle steen van Cremer \& Cie. te Bolsward, die mecr on meer in gebruik kom, eu die wij misschien anders over het hoold zouden zien, duar zij in den catalogus bij de negentiende klasse zijn geplatst, hoewol zij in cle vierde klasse te huis beloorcn.

De Utrechtsche terra cotta fabrijk heeft onk zeer bezienswaardige producten teu toon gesteld, die wel voor ecnige oogenblikken ecne aandachtige beschourving waardig zijn. Daar in dien hoek vinden wij bet zoogenaamde Goudsche tardewerk, ingezouden door J. Pances \& Cre. te Gouda, waar wij veel artikclen terugvinden, die dagclijks in onze keukens worden gebruikt, wannecr wij namelijk nog geeu gebruik makcı van dc gcëmailleerde ijzeren pannen en casserollcn, ingezonden door SoIraepman \& Heumicri te Zwolle. Het is waar, dat veleu bang zijn voor zulk glazuur, daar zij bang zijn voor loodvergiftiging, doch lict product der inzenders is zeer aaubelingswaardig en kan zouder gevar gebruikt worden.

Onder de zinken voorwerpen, ingezouden door H. CuY Litz te Rotterdam, verdient het zinken lautaarnraan bijzonder ure anudacht, daar dit zoodanig is ingerigt, dat het volstrekt uiet kiun lekken, iets waarvan men gewoonlijk $\operatorname{nog}$ al last hecit.

De inarmercu vliezen van A. Sungels Nz. te Dordrecht, zullen u verwouderen en gij zult niet begrijpeu wat er met zulke duune marmeren platen kan gedaan worden, en teregt, maar gij moet ze uit een ander 
oogpunt beschouwen, en wel er uit zien, hoe naauwkenrig de machine loopt waarop zij gezaagd zijn, en dan tot het besluit komen, dat deze stoomzagerij uitmuntend werk moet kumen opleveren.

Het creosoteren en tegen bederf behoeden door andere midielen, van hout is iets van grool aanbelang, waarom wij dan ook even stilstaan bij rasterwerk van gecreosoteerd hout van A. Sxarkise te Amsterdam, en de volgens Boucherie's methode gepraepareerde en reeds gebruikte paal, daar tegen de kolom geplaatst, doch niet in den catalogus te rinden.

Hier vinden wij ook de looden buizen en lijsten, benevens de tiunen buizen van J. ANDRiessens te Roermond, en ons omkeerende, zien wij verschillende mousters louw en een paar bliksemafleiders voor schepen, waarvan wij uwe aandacht verzocken, voor de reep van B. A. Fokker te Middelburg, die voor de helft want- en de andere helft kabelslag is.

Nog merken wij bij het verlaten dezer zaal op de ratjes zonder banden, van Seipgens \& Hulster te- Roermond, die een vreemd gezigt opleveren, doch waarvan wij voorshands het nut niet inzien.

In zaal 13 binnengetreden vinden wij niet veel verscheidenheid, en om hier iets bijzonders an te toonen, zouden wij van de gestelde orde moeten afwijken en de voorwerpen wel aamaken, en zelfs zoodanig dat wij er eeus in konden kijken. Wat toch is van een brandkast de waarde? de goede vulling en het slot. Welnu geen van beiden kan men zien. Voor kagchels, haarden, in cen woord voor alle werktuigen dienende tot ontwikkeling van warmte, moet de rooster-openiug in bepaalde verhouding stian tot de afrocr-opening der verbrandingsproducten, en moet de verbrandingsruimte geevenredigd wezen aan de brandstof, warvoor zij gemaakt zijn, en dit is hier alles niet te zien, waarom wij dan eenvoudig doorgaan, en in de doorgang naar zaal 14 nog opmerken de biezen enveloppes van P. Preterse \& Cie te Gouda, die voor de verzending van flesschen van veel nut zijn, en een veel betere verpakking opleveren dan hooi, stroo, zemelen, of doppen.

De zaal No. 14 die wij nu binneutreden kan niet roemen op sterke verlichting; evenwel zien wij daar in de vensterbank kunst-toumesol van C. \& J. Avis te Westzaan benevens de daarmede gekleurde kaajes; verder de verschillende verpakking van boter, ter verzending naar Oost-Indie, in flessehen en op fust, van H. J. Wiusman Bz. te Amsterdam.

Ten slotte merken wij nog op het borstelwerk van Gerr. Jonker te Amsterdam en de verschillende voorwerpen van gomelastiek van $H$. DE CLerce te Haarlem, waarna wij hoogst voldaan over onze wandeling door de Pandgang het tentoonstellingsgebouw verlaten, vermoeid van het zien van en het drentelen langs alle tentoongestelde voorwerpen.

Welnu, zijt gij voldaan over hetgeen wij gezien hebbeu? Zeker wel, want indien wij alles bij elkander vatten en ons de laatste tentoonstelling te Arnhem in het geheugen terug roepen, dan kumnen wij wel verzekeren, dat de Nederlandsche nijverheid in vele opzigten bepaaldelijk is vooruitgegaan. $\mathrm{Zij}$ is vooruitgegaan, ook, en zelfs niet het minst in die $\mathrm{kwaliteiten}$ die soms voor bijzaken worden gehouden, en dic dan ook de deugdelijkheid van het product niet uitmaken, doch nicttemin van hoog gevigt zijn to achten, nl. belagelijkheid, en vorm: ontegenzeggelijk was er bij vele producten kunstzin, schoonheids-gevoel op te merken, en wij wagen het te zeggen, in hooger 
mate dan vroeger het geval was. Bij meubelen, gesneden houtwerk, enkele bronzen, gehouwen steen, sommige der verlak-werken, was bepaaldelijk vooruitgang in dezen zin op te merken, waarbij de invloed van vertrouwdheid met buitenlandsche producten was te erkennen. Kon het ook wel anders? De spoorwegen, de verlaging van invoerregten, het toenemend vertier, dat alles brengt personen en producten bij elkaar, en doet overal iets goeds erkeunen dat door den oplettenden en waren industrieel gaandeweg wordt opgenomen en overgebragt. De gezegende invloed der verruimde concurrentie is ommiskenbaar op deze schoone tentoonsielling. Concurrentie, niet alleen der voortbrengers onderling, doch ook der consumenten. De rerbruikers bebben in de laatste tien jaren meer gezien dan welligt in dertig jaren te voren. In Londen, Brussel, Parijs, ook in menigte plaatsen der schoone Duitsche industrie, heeft de Nederlander thans producten leeren kennen, die voor vele zaken van dagelijksch gebruik, in schoonheid en lagen prijs, boven de onzen vooruit hebben. De consumateur is moeijelijker geworden, hij denkt er tweemal over, om iets voor $f 60$ hier te koopen, 't geen hij voor de moeite der bestelling binnen een paar dagen voor $f 40$ uit Brussel kan bekomen. Mogen onze fabriekanten dat wel in gedachte houden. Gaat de ijverige fabriekant of handelaar meermalen naar 't buitenland om er de eerste producten in zijn vak te leeren kennen, de verbruikers gaan er ook heen: elke zomer brengen de spoorwegen honderde en duizende Nederlanders binnen de grenzen terug, die, als zij oplettend zijn, niet alleen de schoone natuurtafereelen, doch ook de vrucbtbare industrie van het buitenland hebben leeren kenuen. In één woord, de verbruiker apprecieert beter dan vroeger, en op den duur stelt de verbruiker de wet.

Ook om die redeu hadden wij gaarne gewenscht, dat bij deze tentoonstelling als algemeene regel had mogen gelden, hetgeen slechts door zeer enkele exposanten gedaan werd, al. dat bij elk voorwerp de prijs ware opgeven waarvoor het verkrijgbaar is. Prijs en kwaliteit zijn eigenlijk onafscheidelijk, of liever, de prijs is een der $k$ waliteiten die steeds mede moet in acht genomen worden. 't Geen goed kan zijn voor 60 cents, keur ik welligt af als het 80 cts. host. Zelfs deugdelijkleid en duurzaamheid kunnen te duur geschat worden. Voorwerpen uit metaal vervaardigd kunnen haust zoo mooi zijn als werkelijk porcelein, maar als ik tien porceleinen kamen kan breken voor den prijs waarvoor ik één imitatie-porceleinen bekom, - (in den regel toch breekt men zoo heel veel kannen niet), dan moet toch de prijs hier beslissen. En wat zou een tentoonstelling nog meer nut hebben om den verbruiker voor te lichten, indien men voor de menigte voorwerpen van dagelijksch gebruik, een vergelijking kon maken, en tevens dadelijk de adressen zien, war mon ze let goedkoopst bekomt? En evenzoo voor die producteurs die goedkoop leveren, welk een schoone gelegenheid om dat bekend te maken en uitgebreide claudisie te bekomen! Welk een 
aangenaam gevoel moet het zijn voor den fabriekant, indien hij de producten ran zijn buurman tegen hooger prijs dan de zijnen vindt aangeboden? Zoo zoude elke nationale tentoonstelling een verruimde concurrentie daarstellen, en, ook door het aanlokken van nog meer exposanten, aan het publiek des te beter gelegenheid geven om de Nederlandsche industrie in al hare vertakkingen te beoordeelen.

Een andere opmerking die wij bij het bezoeken dezer tentoonstelling niet mogten weerlouden, was de wensch : „Och, had men een keur dezer producten, thans juist tien jaren geleden, te Londen mogen zien, in dat zeker hoekje vau het kristallen paleis dat door zijn onoogelijkheid de aandacht trok, en waarop de Nederlandsche bezoeker niet zonder teleurstelling den naam van zijn land geplaatst vond! - Welnu, wat in 1851 daar verloren werd, kan in 1862 met glans herwonnen worden!

Doch, zegt men welligt, wat is nu uit een industrieel oogpunt wel het allermerkwaardigste voorwerp? - Dat is een moeijelijke vraag. Ik kan er mij echter onmiddelijk met eere van afmaken, door te herinneren aan onze afspraak, dat ik mij met geene beoordeeling inliet. Dat laten wij aan de jury over. Niet alleen omdat die leden zelve menschen zijn van erkende ondervinding en verdienste, maar eene geheele jury ziet ook veel beter, elk in zijn vak, dan een enkel persoon. Ook dient men het eerst eens te zijn, in welken zin men de merkwaardigheid bedoelt. Merkwaardigst b. v. door de meeste nuttigheid, of fraaiheid, of moeijelijkheid in bewerking, of vreemdheid, of goedkoopheid? Door elk dezer $\mathrm{kwaliteiten} \mathrm{kan} \mathrm{een} \mathrm{product} \mathrm{afzonderlijk} \mathrm{merkwaardig} \mathrm{zijn} \mathrm{,} \mathrm{maar} \mathrm{de} \mathrm{bespreking}$ daarvan zou zeer ver leiden. - Wilt gij echter genoegen nemen met eene welligt niet vermoedde aanwijzing van iets dat in elk geval $u_{i}$ terst belangrijk is, dan verwijzen wij u naar den catalogus $\mathrm{N}^{\text {s. }} 1135$, daar vindt gij een der meest belangwekkende zaken der geheele tentoonstelling, als product eener nieuwe tak van kunst-industrie, die hoogst moeijelijk is in nitvoering

En hiermede nemen wij afseheid, in de hoop van elkander over vijf jaren bij dezelfde gelegenheid weder te ontmoeten, en weder te kunnen zeggen, dat de Nederlandsche nijverheid in vergelijk met de tentoonstelling van 1861, is voornitgegaan.

's G.

F. N. 